\title{
Evaluation of genetic variability in the regenerated population of sugarcane
}

\author{
Shahla Karim Baloch ${ }^{1 *}$, Masroor Ahmed Bhutto ${ }^{1}$, Rehana Anjum², \\ Ghulam Shah Nizamani ${ }^{3}$, Aneela Yasmeen Bughio ${ }^{3}$, Imtiaz Ahmed \\ $\mathrm{Khan}^{3}$, Nighat Seema Soomro ${ }^{3}$, Kashamala Baloch ${ }^{4}$, Asghar Ali \\ Rajper $^{5}$, Arshad Ali Kaleri ${ }^{5}$ and Rameez Raja Kaleri ${ }^{5}$ \\ 1. Department of Biotechnology Sindh Agriculture University, Tandojam-Pakistan \\ 2. Central Cotton Research Institute Multan-Pakistan \\ 3. Nuclear Institute of Agriculture, Tando Jam-Pakistan \\ 4. Information Technology Centre-Pakistan \\ 5. Department of Plant Breeding \& Genetics, Sindh Agriculture University, Tando Jam-Pakistan \\ *Corresponding Author: shahlabaloch@gmail.com \\ Citation
}

Shahla Karim Baloch, Masroor Ahmed Bhutto, Rehana Anjum, Ghulam Shah Nizamani, Aneela Yasmeen Bughio, Imtiaz Ahmed Khan, Nighat Seema Soomro, Kashamala Baloch, Asghar Ali Rajper, Arshad Ali Kaleri and Rameez Raja Kaleri. Evaluation of genetic variability in the regenerated population of sugarcane. Pure and Applied Biology. Vol. 7, Issue 1, pp26-32. http://dx.doi.org/10.19045/bspab.2018.70004

\begin{tabular}{llll}
\hline \hline Received: 16/10/2017 & Revised: 18/12/2017 & Accepted: 28/12/2017 & Online First: 01/01/2018 \\
\hline \hline
\end{tabular}

\section{Abstract}

The direct regeneration is highly valuable procedure on large scale for producing of sugarcane infection plant material of verities and can help in rapid displaying and production of latest varieties by the multiplication. Rapid and efficient protocol was used in sugarcane through in vitro culture for direct regeneration. The (Murashig Skoog) MS average incremented among various concentration of indole-3acetic acid (IAA) and indole-3-butyric acid (IBA), kinetin (Kn) and 2, 4-Dichlorophenoxyacetic acid (2, 4D) were used for through regeneration in sugarcane. The results indicated that maximum number of shoots with shoot length were observed in NIA-2004 variety on MS average incremented with (6.00 mg-1) IAA+ (1.00 MG-1) Kinetin and (0.5 mg-1) 2, 4-D, the smallest shoot numbers + length of shoot was observed in the NIA-98 with percentage of (MS+Sugar $40 \mathrm{~g}-1)$ in control conditions. The growth of mutant chlorophyll represent that direct effect of regeneration could not hold up the loyalty hereditary but can be serve as the major source for assessing the present aneuploidy. The highest root number was observed in NIA- 2011 in percentage of (MS+ $1.00 \mathrm{mg}-1) \mathrm{IBA}+(20 \mathrm{~g})$ sugar, whereas lowers root number was found on (MS+ $1.00 \mathrm{mg}-1) \mathrm{IBA}+(10 \mathrm{~g})$ sugar. in NIA-98. The maximum root length was obtained in NIA-2011 under the concentration of MS $+1.00 \mathrm{mg} \mathrm{l}^{-1}+20 \mathrm{~g} \mathrm{l}^{-1}$ sugar and minimum root length was achieved in NIA98 under the concentration of MS $+1.00 \mathrm{mg} \mathrm{l}^{-1}+10 \mathrm{~g} \mathrm{l}^{-1}$. It was concluded that the best shoot induction was observed under the concentration of MS average including $6.00 \mathrm{mg} \mathrm{l}^{-1} \mathrm{IAA}+1.00 \mathrm{mg} \mathrm{l}^{-1}$ kinetin +0.5 $\mathrm{mg} \mathrm{l}^{-1} 2$, 4-D + sugar $40 \mathrm{~g}$ and $\mathrm{MS}+1.00 \mathrm{mg} \mathrm{l}^{-1} \mathrm{IBA}+20 \mathrm{~g}$ sugar proved best concentration for root induction for direct regeneration in sugarcane.

Keywords: Direct regeneration; Genetic variability; Plant growth hormones; Sugarcane; Tissue culture \section{Introduction}

Sugarcane (Saccharum officinarum) has primary importance among commercial crops in Pakistan. Commercially, sugar cane is propagated from the cut of the stem with each chart or set having two or three buds. After the development of the clone / variety, the main bottleneck in the clone or variety 
extension is the slow propagation rate through the formal method, which requires several years [1]. Many reasons have been reported for low production of sugarcane from them an important is inability of rapid multiplication of see practice. In this procedure favorable clone is can be clear, which takes about 6 to 7 years normally for getting effective quality of better planting material. This high time consuming process can be because of a large bottleneck in effective breeding program [2]. Plant tissue culture is an assemblage of procedures employed to sustain or culture plant groups, tissues otherwise appendages below sterilized situations in a nutrient culture average of identified concerto. Today, the technique of plant tissue culture has become a potent tool to study, solve basic problems and applied in plant biotechnology [3-5] conducted initial trials to regenerate plants through in vitro techniques. Many writers have developed procedures for the in vitro regeneration of sugarcane during corn cultivation, axillary blossom, furthermore shoot pour culture [6-8]. The growth of tissue culture technology for the rapid generation of disease-free planting material has been an important step towards sufficient seed production, faithful to the character and quality of sugarcane [9]. Thus, the application of plant tissue culture techniques provides an alternative method for the propagation and improvement of sugarcane [10]. Plant tissue culture offers the best methodology through the micropropagation of sugarcane for planting quality and planting material at a quicker pace in a shorter period. Tissue culture preserve add to the spread probable near 20-35 moments [11].

\section{Materials and methods}

The current investigation was performed at Laboratory of Tissue Culture, Division of Plant Breeding and Genetics, NIA Nuclear Institute of Agriculture, Tandojam, Sindh, Pakistan during the 2016-17 through co- ordination with outside fresh since microorganisms through cleaning by ethanol (70 $\%$ ) for one minute, followed by in $10 \%$ commercial bleach $(5.25 \% \mathrm{NaOCI})$ for with cleaned (03) times through pure condensed water.

The explants Department of Biotechnology, Sindh, Pakistan to evaluate of genetic variability in sugarcane through direct regeneration population. The explants material were taken from 6 months old of (03) sugarcane genetics viz. NIA-98, NIA2004 plus NIA-2011 was collected from Experimental Farm, Nuclear Institute of Agriculture, Tando Jam. The trials were conducted under complete randomized block design among (03) replications. Meristematic stem pours was removed also materials were cultured on MS average (1962), MS + sugar $40 \mathrm{~g} \mathrm{l}^{-1}$ (control), MS (+2.00 mg1-1) IAA+ (1.00 mhg-1-1), Kin+ (0.50 mg-1-1) 2 to 4-D + sugar (40 gm-1-1), MS+ (4.00 mg-1-1), $\mathrm{IAA}+(1.00 \mathrm{mg}-1-1), \mathrm{Kin}+(0.50 \mathrm{mg}-1-1), 2$ to 4-D+ sugar (40 g-1-1), MS+ (6.00 mg-11), IAA+ (1,00 mg-1-1), Kin+ (O.50 mg-11), 2 to 4-D+ sugar (40 g-1-1), with (2.00 mg1-1 thiamine vitamin, Myo inositol for the induction of shoot and MS+ (1.00 mg-1-1), $\mathrm{IBA}+(10 \mathrm{~g})$ sugar-1-1 + MS+ (1.00 mg-1-1), IBA+(50 g) sugar-1-1 for the induction of shoot. The under study characteristics were length of shoot, shoot numbers cm bottlep-1, number of chlorophyll mutants' bottle ${ }^{-1}$, number of roots bottle ${ }^{-1}$ and root length $(\mathrm{cm})$ bottle $^{-1}$. All cultures were carried out with MS average increased by diverse applications of hormones, vitamins between 1 to $5 \%$ sucrose; $\mathrm{pH}$ was maintained 5.7-5.8 and media coagulated through $3.0 \mathrm{~g} \mathrm{l}^{-1}$ gelrite ahead of autoclaving $\left(121^{\circ} \mathrm{C}\right.$ plus $15 \mathrm{lbs}$ for 20 minutes). Every culture be put in growth room at $25 \pm{ }^{0} \mathrm{C}$ with $18 / 6 \mathrm{~h}$ photo period intensity of light 2000 lux.

The research data was proofed also mattered to factorial design of assessment of variation (ANOVA) below linear replicas of statistics 
to examine numerical variations between various natures of sugarcane by using computer program, Student journal of Statistix (SWX), Report 8.1 [12]. Additional smallest amount important variation (LSD) analysis was besides functional to analysis the stage of importance surrounded by diverse grouping denotes [13].

\section{Results and discussion}

\section{Shoot bottle- ${ }^{1}$ numbers}

The analysis of variance statistical showed that verities, percentage and their association were observed significantly higher for the shoot number at significantly higher $(5 \%)$ level of probability details are represented in (Table 1). The findings of verities showed that higher shoot number was observed (14.66) in NIA-2004 and minimum number of shoots was recorded (10.75) in NIA-2011. The result of concentrations showed maximum number of shoots were achieved (20.88) under concentrations of (MS+ 6.00 mg-1-1), (Kin+ 0.5 mg-1-1), (IAA+ 1.00 mg1-1) for 2 to 4-D+ sugar (40 g-1-1) and lowest 2.88 in percentage of (MS+ sugar $40 \mathrm{~g}-1-1)$. The association of verities vs concentration showed that higher shoot number was observed 23.00 in (NIA-2004) at the concentration of (MS+ 6,00 mg-1-1), (IAA+ $1.00 \mathrm{mg}-1-1),(\mathrm{Kin}+0.50 \mathrm{mg}-1-1), 2$ to $4-\mathrm{D}$ sugar (40 g-1-1), lowest shoot number was found 2.33 in the concentration of (MS sugar $40 \mathrm{~m}-1-1$ ) in (NIA-98. [14] showed that high ratio of cytokinin and auxin was essential and better for production of adventitious shoots rather than cytokinin alone in sugarcane. [9] found the highest multiple shoot were found scheduled MS average with $3.00 \mathrm{mg} \mathrm{l}^{-1} \mathrm{BAP}$ $+2.00 \mathrm{mg} \mathrm{l}^{-1} \mathrm{IAA}+2.00 \mathrm{mg}^{-1} \mathrm{Kin}$ respectively.

Table 1. Number of shoots bottle ${ }^{-1}$ as affected under different concentrations of plant growth hormones in sugarcane varieties

\begin{tabular}{|c|c|c|c|c|}
\hline \multirow{2}{*}{ Concentrations } & \multicolumn{3}{|c|}{ Varieties } & \multirow[t]{2}{*}{ Mean } \\
\hline & NIA-98 & NIA-2004 & NIA-2011 & \\
\hline MS + sugar $40 \mathrm{~g} \mathrm{l}^{-1}$ (control) & $2.33 \mathrm{~h}$ & $2.66 \mathrm{gh}$ & $3.66 \mathrm{~g}$ & $2.88 \mathrm{~d}$ \\
\hline $\begin{array}{l}\mathrm{MS}+2.00 \mathrm{mg} \mathrm{l}^{-1} \mathrm{IAA}+1.00 \mathrm{mg} \mathrm{l}^{-1} \mathrm{kin}+ \\
0.50 \mathrm{mg} \mathrm{l}^{-1} 2,4-\mathrm{D}+\operatorname{sugar} 40 \mathrm{~g} \mathrm{l}^{-1}\end{array}$ & $15.00 \mathrm{c}$ & $18.33 \mathrm{~b}$ & $12.66 \mathrm{~d}$ & $15.33 \mathrm{~b}$ \\
\hline $\begin{array}{l}\mathrm{MS}+4.00 \mathrm{mg} \mathrm{l}^{-1} \mathrm{IAA}+1.00 \mathrm{mg} \mathrm{l}^{-1} \mathrm{kin}+ \\
0.50 \mathrm{mg} \mathrm{l}^{-1} 2,4-\mathrm{D}+\operatorname{sugar} 40 \mathrm{~g} \mathrm{l}^{-1}\end{array}$ & $11.00 \mathrm{e}$ & $14.66 \mathrm{c}$ & $9.00 \mathrm{f}$ & $11.55 \mathrm{c}$ \\
\hline $\begin{array}{l}\mathrm{MS}+6.00 \mathrm{mg} \mathrm{l}^{-1} \mathrm{IAA}+1.00 \mathrm{mg} \mathrm{l}^{-1} \mathrm{kin}+ \\
0.50 \mathrm{mg} \mathrm{l}^{-1} 2,4-\mathrm{D}+\operatorname{sugar} 40 \mathrm{~g} \mathrm{l}^{-1}\end{array}$ & $22.00 \mathrm{a}$ & $23.00 \mathrm{a}$ & $17.66 \mathrm{~b}$ & $20.88 \mathrm{a}$ \\
\hline Mean & $12.58 \mathrm{~b}$ & $14.66 \mathrm{a}$ & $10.75 \mathrm{c}$ & \\
\hline
\end{tabular}

Varieties, SE (0.2683), LSD (5\%) (0.5564), Concentrations, SE (0.3098), LSD (5\%) (0.6424),

V x C, SE (0.5365), LSD (5\%) (1.1127)

\section{Length bottle shoot $\mathrm{cm}$}

The analysis of variance statistically showed that the concentration and verities as well as their association was observed significantly higher at the level of $(5 \%)$ probability, results are showed in (Table 2). The findings of verities showed that higher length of shoot was observed $11.42 \mathrm{~cm}$ for the verity NIA2004 and minimum shoot length was recorded $(8.04 \mathrm{~cm})$ in NIA-2011. The result of concentrations indicated that maximum shoot length were achieved $(12.77 \mathrm{~cm})$ under concentration of $\mathrm{MS}+6.00 \mathrm{mg} \mathrm{l}^{-1} \mathrm{IAA}+1.00$ $\mathrm{mg} \mathrm{l}^{-1} \mathrm{Kin}+0.50 \mathrm{mg} \mathrm{l}^{-1} 2,4-\mathrm{D}+\operatorname{sugar} 40 \mathrm{~g}$ $1^{-1}$, and minimum $(6.89 \mathrm{~cm})$ under concentration of $\mathrm{MS}+\operatorname{sugar} 40 \mathrm{~g} \mathrm{l}^{-1}$. The interaction of varieties $\mathrm{x}$ concentrations showed that maximum shoot length were recorded $(16.35 \mathrm{~cm})$ in NIA-2004 under concentration of $\mathrm{MS}+6.00 \mathrm{mg} \mathrm{l}^{-1} \mathrm{IAA}+1.00$ 
$\mathrm{mg} \mathrm{l}^{-1} \mathrm{Kin}+0.50 \mathrm{mg} \mathrm{l}^{-1} 2,4-\mathrm{D}+\operatorname{sugar} 40 \mathrm{~g}$ $\mathrm{1}^{-1}$, and minimum shoot length were observed $(5.73 \mathrm{~cm})$ in NIA-2011 under concentration of $\mathrm{MS}+$ sugar $40 \mathrm{~g} \mathrm{l}^{-1}$. The results agreed with $[11,12]$ that MS average surrounding
$1.00 \mathrm{mg} \mathrm{l}^{-1} \mathrm{IAA}+1.00 \mathrm{mg} \mathrm{l}^{-1} \mathrm{IBA}+1.00 \mathrm{mg}$ $1^{-1}$ Kinetin as best medium for shoot length, while [15], reported that $1.00 \mathrm{mg} \mathrm{l}^{-1} \mathrm{BAP}$ concentration proofed best in sugarcane.

Table 2. Shoots bottle ${ }^{-1}$ as affected under different concentrations of plant growth hormones in sugarcane varieties

\begin{tabular}{|c|c|c|c|c|}
\hline \multirow{2}{*}{ Concentrations } & \multicolumn{3}{|c|}{ Varieties } & \multirow[t]{2}{*}{ Mean } \\
\hline & NIA-98 & NIA-2004 & NIA-2011 & \\
\hline $\mathrm{MS}+$ sugar $40 \mathrm{~g} \mathrm{l}^{-1}$ (control) & $6.38 \mathrm{~g}$ & $8.57 \mathrm{e}$ & $5.73 \mathrm{~h}$ & $6.89 \mathrm{~d}$ \\
\hline $\begin{array}{l}\mathrm{MS}+2.00 \mathrm{mg} \mathrm{l}^{-1} \mathrm{IAA}+1.00 \mathrm{mg} \mathrm{l}^{-1} \mathrm{kin} \\
+0.50 \mathrm{mg} \mathrm{l}^{-1} 2,4-\mathrm{D}+\operatorname{sugar} 40 \mathrm{~g} \mathrm{l}^{-1}\end{array}$ & $10.24 \mathrm{c}$ & $11.53 \mathrm{~b}$ & $8.47 \mathrm{e}$ & $10.08 \mathrm{~b}$ \\
\hline $\begin{array}{l}\mathrm{MS}+4.00 \mathrm{mg} \mathrm{l}^{-1} \mathrm{IAA}+1.00 \mathrm{mg} \mathrm{l}^{-1} \mathrm{kin} \\
+0.50 \mathrm{mg} \mathrm{l}^{-1} 2,4-\mathrm{D}+\operatorname{sugar} 40 \mathrm{~g} \mathrm{l}^{-1}\end{array}$ & $8.55 \mathrm{e}$ & $9.25 \mathrm{~d}$ & $7.64 \mathrm{f}$ & $8.48 \mathrm{c}$ \\
\hline $\begin{array}{l}\mathrm{MS}+6.00 \mathrm{mg} \mathrm{l}^{-1} \mathrm{IAA}+1.00 \mathrm{mg} \mathrm{l}^{-1} \mathrm{kin} \\
+0.50 \mathrm{mg} \mathrm{l}^{-1} 2,4-\mathrm{D}+\operatorname{sugar} 40 \mathrm{~g} \mathrm{l}^{-1}\end{array}$ & $11.63 \mathrm{~b}$ & $16.35 \mathrm{a}$ & $10.34 \mathrm{c}$ & $12.77 \mathrm{a}$ \\
\hline Mean & $9.20 \mathrm{~b}$ & $11.42 \mathrm{a}$ & $8.04 \mathrm{c}$ & \\
\hline
\end{tabular}

Varieties, SE (0.0844), LSD (5\%) (0.1751), Concentrations, SE (0.0975), LSD (5\%) (0.2021),

V x C, SE (0.1688), LSD (5\%) (0.3501)

\section{Chlorophyll mutant's bottle-1 number}

The analysis of variance statistically showed that concentration and verities as well as their association were observed significantly higher for the chlorophyll mutant at the level of $(5 \%)$ probability and results are described in the (Table 3). The findings of verities showed that higher chlorophyll mutant was observed (4.33) in NIA-2011 and minimum chlorophyll mutants were recorded (2.33) in NIA-98. The result of absorptions showed that maximum chlorophyll mutants were achieved (5.33) under absorption of MS + $4.00 \mathrm{mg} \mathrm{l}^{-1} \mathrm{IAA}+1.00 \mathrm{mg} \mathrm{l}^{-1} \mathrm{Kin}+0.5 \mathrm{mg} \mathrm{l}^{-}$ ${ }^{1}$ 2, 4-D + sugar $40 \mathrm{~g} \mathrm{l}^{-1}$, and minimum (0.00) under concentration of MS + sugar $40 \mathrm{~g} \mathrm{l}^{-1}$. The interaction of varieties and concentrations showed that the maximum chlorophyll mutants were observed (8.00) in NIA-2011 under concentration of MS +4.00 $\mathrm{mg} \mathrm{l}^{-1} \mathrm{IAA}+1.00 \mathrm{mg} \mathrm{l}^{-1} \mathrm{Kin}+0.5 \mathrm{mg} \mathrm{l}^{-1} 2$, $4-\mathrm{D}+$ sugar $40 \mathrm{~g} \mathrm{l}^{-1}$, and minimum chlorophyll mutants were observed (0.00) in NIA-98, NIA-2004 and NIA-2011 under concentration of MS + sugar $40 \mathrm{~g} \mathrm{l}^{-1}$. The results supported by [16] Chlorophyll was utilized in the biochemical, physiological and genetic marker analysis, whereas the [17], reported that formation of chlorophyll remain under control in cytoplasmic gene and nuclear, while the chlorophyll mutants utilized for the genetic fidelity tests of evaluations.

\section{Root bottle-1 numbers}

The analysis of variance statistically showed that concentration and verities were observed significantly higher with their association was found significantly high at the level of (5\%) probability; details are given in (Table $4)$. The findings of current study showed that higher root number was observed 9.26 in (NIA-2004) and lowest was found (6.53) in (NIA-98). The findings of concentrations showed maximum number of roots were achieved (11.77) under concentration of MS $+1.00 \mathrm{mg} \mathrm{IBA}+\operatorname{sugar} 20 \mathrm{~g} \mathrm{l}^{-1}$, and minimum (4.22) under concentration of $\mathrm{MS}+1.00 \mathrm{mg}$ IBA + sugar $10 \mathrm{~g} \mathrm{l}^{-1}$. The interaction of varieties $\mathrm{X}$ concentration indicated that greatest number of roots was pragmatic (16.66) in NIA-2011 under concentration of $\mathrm{MS}+1.00 \mathrm{mg}$ IBA + sugar $20 \mathrm{~g} \mathrm{l}^{-1}$, and 
minimum number of roots were observed (3.33) in NIA-98, under concentration of MS $+1.00 \mathrm{mg}$ IBA + sugar $10 \mathrm{~g} \mathrm{l}^{-1}$. The results agreed with [18].

later the formation of root was reduced by mixing of auxins in the medium nutrient. The strongest growth was observed through
(IBA) by the (1.00 mg-1-1) concentration was achieved greatest number of roots explants $^{-1}$. The results also fully supported by $[19,20]$ that MS average auditioned by 1.00 $\mathrm{mg} \mathrm{l}^{-1}$ Kinetin $+1.5 \mathrm{mg} \mathrm{l}^{-1} \mathrm{BAP}+1.5 \mathrm{mg} \mathrm{l}^{-1}$ IBA gave superior results for root induction in sugarcane.

Table 3. Chlorophyll mutant's as affected under different concentrations of plant growth hormones in sugarcane varieties

\begin{tabular}{|c|c|c|c|c|}
\hline \multirow{2}{*}{ Concentrations } & \multicolumn{3}{|c|}{ Varieties } & \multirow[t]{2}{*}{ Mean } \\
\hline & NIA-98 & NIA-2004 & NIA-2011 & \\
\hline $\mathrm{MS}+$ sugar $40 \mathrm{~g} \mathrm{l}^{-1}$ (control) & $0.00 \mathrm{~h}$ & $0.00 \mathrm{~h}$ & $0.00 \mathrm{~h}$ & $0.00 \mathrm{~d}$ \\
\hline $\begin{array}{l}\mathrm{MS}+2.00 \mathrm{mg} \mathrm{l}^{-1} \mathrm{IAA}+1.00 \mathrm{mg} \mathrm{l}^{-1} \mathrm{kin} \\
+0.50 \mathrm{mg} \mathrm{l}^{-1} 2,4-\mathrm{D}+\operatorname{sugar} 40 \mathrm{~g} \mathrm{l}^{-1}\end{array}$ & $1.67 \mathrm{~g}$ & $2.66 \mathrm{fg}$ & $4.00 \mathrm{c}-\mathrm{e}$ & $2.77 \mathrm{c}$ \\
\hline $\begin{array}{l}\mathrm{MS}+4.00 \mathrm{mg} \mathrm{l}^{-1} \mathrm{IAA}+1.00 \mathrm{mg} \mathrm{l}^{-1} \mathrm{kin} \\
+0.50 \mathrm{mg} \mathrm{l}^{-1} 2,4-\mathrm{D}+\operatorname{sugar} 40 \mathrm{~g} \mathrm{l}^{-1}\end{array}$ & $3.00 \mathrm{ef}$ & $5.00 \mathrm{bc}$ & $8.00 \mathrm{a}$ & $5.33 \mathrm{a}$ \\
\hline $\begin{array}{l}\mathrm{MS}+6.00 \mathrm{mg} \mathrm{l}^{-1} \mathrm{IAA}+1.00 \mathrm{mg} \mathrm{l}^{-1} \mathrm{kin} \\
+0.50 \mathrm{mg} \mathrm{l}^{-1} 2,4-\mathrm{D}+\operatorname{sugar} 40 \mathrm{~g} \mathrm{l}^{-1}\end{array}$ & $4.66 \mathrm{~b}-\mathrm{d}$ & $3.66 \mathrm{~d}-\mathrm{f}$ & $5.33 \mathrm{~b}$ & $4.55 \mathrm{~b}$ \\
\hline Mean & $2.33 \mathrm{~b}$ & $2.83 \mathrm{~b}$ & $4.33 \mathrm{a}$ & \\
\hline
\end{tabular}

Varieties, SE (0.2865), LSD (5\%) (0.5941), Concentrations, SE (0.3308), LSD (5\%) (0.6860),

V x C, SE (0.5730), LSD (5\%) (1.1882)

Table 4. Number of roots as affected under different concentrations of plant growth hormones in sugarcane varieties

\begin{tabular}{|l|l|l|l|l|}
\hline \multirow{2}{*}{ Concentrations } & \multicolumn{3}{c|}{ Varieties } & \multirow{2}{*}{ Mean } \\
\cline { 2 - 5 } & NIA-98 & NIA-2004 & NIA-2011 & \\
\hline $\mathrm{MS}+1.00 \mathrm{mg} \mathrm{l}^{-1} \mathrm{IBA}+10 \mathrm{~g} \mathrm{l}^{-1}$ sugar & $3.33 \mathrm{f}$ & $4.33 \mathrm{ef}$ & $5.00 \mathrm{~d}-\mathrm{f}$ & $4.22 \mathrm{c}$ \\
\hline $\mathrm{MS}+1.00 \mathrm{mg} \mathrm{l}^{-1} \mathrm{IBA}+20 \mathrm{~g} \mathrm{l}^{-1}$ sugar & $8.33 \mathrm{~b}-\mathrm{d}$ & $10.33 \mathrm{~b}$ & $16.66 \mathrm{a}$ & $11.77 \mathrm{a}$ \\
\hline $\mathrm{MS}+1.00 \mathrm{mg} \mathrm{l}^{-1} \mathrm{IBA}+30 \mathrm{~g} \mathrm{l}^{-1}$ sugar & $7.66 \mathrm{~b}-\mathrm{e}$ & $9.66 \mathrm{~b}$ & $10.33 \mathrm{~b}$ & $9.22 \mathrm{~b}$ \\
\hline $\mathrm{MS}+1.00 \mathrm{mg} \mathrm{l}^{-1} \mathrm{IBA}+40 \mathrm{~g} \mathrm{l}^{-1}$ sugar & $7.33 \mathrm{~b}-\mathrm{e}$ & $8.00 \mathrm{~b}-\mathrm{d}$ & $9.00 \mathrm{bc}$ & $8.11 \mathrm{~b}$ \\
\hline $\mathrm{MS}+1.00 \mathrm{mg} \mathrm{l}^{-1} \mathrm{IBA}+50 \mathrm{~g} \mathrm{l}^{-1}$ sugar & $6.00 \mathrm{c}-\mathrm{f}$ & $5.33 \mathrm{~d}-\mathrm{f}$ & $5.33 \mathrm{~d}-\mathrm{f}$ & $5.55 \mathrm{c}$ \\
\hline Mean & $6.53 \mathrm{~b}$ & $7.53 \mathrm{~b}$ & $9.26 \mathrm{a}$ & \\
\hline
\end{tabular}

Varieties, SE (0.7724), LSD (5\%) (1.5822), Concentrations, SE (0.9972), LSD (5\%) (2.0426),

V x C, SE (1.7272), LSD (5\%) (3.5379)

\section{Length of root bottle-1 cm}

The analysis of variance statistically represent that concentration and verities were found significantly higher, whereas their association was also observed significantly high at the level of (5\%) probability, details are described in (Table 5). The findings of our study showed that highest length of root was observed $6.86 \mathrm{~cm}$ in the (NIA-2011) and minimum root length was recorded $(5.06 \mathrm{~cm})$ in NIA-98. The result of concentrations showed that maximum root length was achieved $(8.00 \mathrm{~cm})$ under concentration of $\mathrm{MS}+1.00 \mathrm{mg} \mathrm{IBA}+\operatorname{sugar} 20 \mathrm{~g} \mathrm{l}^{-1}$, and minimum root length $(3.00 \mathrm{~cm})$ under concentration of $\mathrm{MS}+1.00 \mathrm{mg} \mathrm{IBA}+$ sugar $10 \mathrm{~g} \mathrm{l}^{-1}$. The interaction of varieties $\mathrm{x}$ 
concentrations showed that maximum root length was recorded $(9.00 \mathrm{~cm})$ in NIA-2011 under concentration of MS + $1.00 \mathrm{mg}$ IBA + sugar $20 \mathrm{~g} \mathrm{l}^{-1}$, and minimum root length was observed $(2.33 \mathrm{~cm})$ in NIA-98, under concentration of MS + $1.00 \mathrm{mg}$ IBA + sugar $10 \mathrm{~g} \mathrm{l}^{-1}$. The results supported by $[19,20]$.

Table 5. Root length $(\mathrm{cm})$ as affected under different concentrations of plant growth hormones in sugarcane varieties

\begin{tabular}{|l|l|l|l|l|}
\hline \multirow{2}{*}{ Concentrations } & \multicolumn{3}{|c|}{ Varieties } & \multirow{2}{*}{ Mean } \\
\cline { 2 - 4 } & NIA-98 & NIA-2004 & NIA-2011 & \\
\hline $\mathrm{MS}+1.00 \mathrm{mg} \mathrm{l}^{-1} \mathrm{IBA}+10 \mathrm{~g} \mathrm{l}^{-1}$ sugar & $2.33 \mathrm{i}$ & $2.66 \mathrm{hi}$ & $4.00 \mathrm{fg}$ & $3.00 \mathrm{e}$ \\
\hline $\mathrm{MS}+1.00 \mathrm{mg} \mathrm{l}^{-1} \mathrm{IBA}+20 \mathrm{~g} \mathrm{l}^{-1}$ sugar & $7.66 \mathrm{bc}$ & $7.33 \mathrm{bc}$ & $9.00 \mathrm{a}$ & $8.00 \mathrm{a}$ \\
\hline $\mathrm{MS}+1.00 \mathrm{mg} \mathrm{l}^{-1} \mathrm{IBA}+30 \mathrm{~g} \mathrm{l}^{-1}$ sugar & $6.66 \mathrm{~cd}$ & $6.66 \mathrm{~cd}$ & $8.00 \mathrm{ab}$ & $7.11 \mathrm{~b}$ \\
\hline $\mathrm{MS}+1.00 \mathrm{mg} \mathrm{l}^{-1} \mathrm{IBA}+40 \mathrm{~g} \mathrm{l}^{-1} \mathrm{sugar}$ & $5.00 \mathrm{ef}$ & $6.00 \mathrm{de}$ & $7.33 \mathrm{bc}$ & $6.11 \mathrm{c}$ \\
\hline $\mathrm{MS}+1.00 \mathrm{mg} \mathrm{l}^{-1} \mathrm{IBA}+50 \mathrm{~g} \mathrm{l}^{-1}$ sugar & $3.66 \mathrm{gh}$ & $4.66 \mathrm{fg}$ & $6.00 \mathrm{de}$ & $4.77 \mathrm{~d}$ \\
\hline Mean & $5.06 \mathrm{~b}$ & $5.46 \mathrm{~b}$ & $6.86 \mathrm{a}$ & \\
\hline
\end{tabular}

Varieties, SE (0.2690), LSD (5\%) (0.5511), Concentrations, SE (0.3473), LSD (5\%) (0.7115),

V x C, SE (0.6016), LSD (5\%) (1.2323)

\section{Conclusions}

It was concluded that the best shoot induction was observed under the concentration of MS average including $6.00 \mathrm{mg}$ l-1 IAA $+1.00 \mathrm{mg}$ 1-1 kinetin + 0.5 mg 1-1 2, 4-D + sugar $40 \mathrm{~g}$ and $\mathrm{MS}+1.00 \mathrm{mg} \mathrm{1-1} \mathrm{IBA} \mathrm{+} 20 \mathrm{~g}$ sugar proved best concentration for root induction for direct regeneration in sugarcane.

\section{Authors' contributions}

Conceived and designed the experiments: SK Bloch, MA Bhutto \& R Anjum, Performed the experiments: GS Nizamani, AY Buhio \& I Ahmed, Analyzed the data:, NS Soomro \& K Baloch, Contributed materials/ analysis/ tools: AA Rajpar \& AA Kaleri, Wrote the paper:. SK Baloch \& RR Kaleri.

\section{References}

1. Siddiqui SH, Khan IA, Khatri and Nizamani GS (1994). Rapid multiplication of sugarcane through micropropagation. Pak J Agri Res 15: 134-136.

2. Cheema KL and Hussain M (2004). Micropropagation of sugarcane through apical bud and axillary bud. Int J Agri \& Bio 6(2): 257-259.
3. Yadav SA, Ahmad J, Rastogi and Lal M (2012). Tissue culture strategies in sugarcane (Saccharum officinarum L.). Int J Pharma. \& Bio Sci 3(2): 427-441.

4. Nickell LG (1964). Tissue culture of sugarcane, another research tool. Hawaiian Planters Res 57: 223-229.

5. Heinz DJ and Mee GW (1969). Plant differentiation from callus tissue of Saccharum species. Crop Sci 9:346-348.

6. Lee TSG (1983). Multiplication of sugarcane by apex culture. Tumalba 36: 231-235.

7. Hu CY and Wang PJ. Handbook of plant cell culture.P-123-25.

8. Milton J and Alien D (1995). Breeding of field crops. $4^{\text {th }}$ Edition 134-135.

9. Belete $\mathrm{G}$ (2017). Review on in vitro propagation of sugarcane to advance the value of tissue culture. Agri Res \& Tech 5(4): 1-7.

10. Sengar K, Sengar R, Garg SK (2011). The effect of in vitro environmental conditions on some sugarcane varieties for micro propagation. Afric J Biotech 10(75): 17122-17126. 
11. Snyman S, Meyer G, Richards J, Ramgareeb S and Huckett (2006). Refining the application of direct embryogenesis in sugarcane: effect of the developmental phase of leaf disc explants and the timing of DNA transfer on transformation efficiency. Plant Cell Reports 25(10): 1016- 1023.

12. Analytical Software Statistix 8.1 User's Manual, Tallahassee, FL (2005).

13. Gomez KA and Gomez AA (1984). Statistical Procedure for Agricultural Research, (2 eds.), Wiley, New York, USA pp 680.

14. Jagadeesh B, Kumar M, Shekhar M and Udhakar P (2011). Amenability of the sugarcane variety 2005 t 16 to shoot tip culture. J Sugarcane Res 1(2): 75-77.

15. Khan IA, Dahot MU, SeemaN, Yasmeen S, Bibi S, Raza G, Khatri A and Naqvi MH (2009). Direct regeneration of sugarcane plantlets: a tool to unravel genetic heterogeneity. Pak J Bot 41(2): 797-814.

16. Khan SA, Dahot UM, Yasmin S, Khatri A, Seema N and Naqvi MH (2006).
Effect of sucrose and growth regulators on the micropropagation of sugarcane clones. Pak J Bot 38(4): 961-967.

17. Mangrio G, Sughra A, Simair A, Rafique M, Muhammad SM, Shereen N and Dahot UM (2014). In vitro regenerability of different sugarcane (Saccharum officinarum L.) varieties through shoot tip culture. Pak J Biotechnol 11(1): 1323.

18. Svetleva DL (2004). Induction of chlorophyll mutants in common bean under the action of chemical mutagens ENU and EMS. J Central European Agric 5: 85-90.

19. Van HAM (1998). Breading Theory and Practical Application. Cambridge University Press; 1-40.

20. Dinesh P. Thirunavukkarasu, Saraniya $\mathrm{AR}$ and Ramanathan T (2015). In vitro studies of sugarcane variety co-91017 through micropopagation of shoot tip culture. Adv Plants Agric Res 2(6): 234238. 